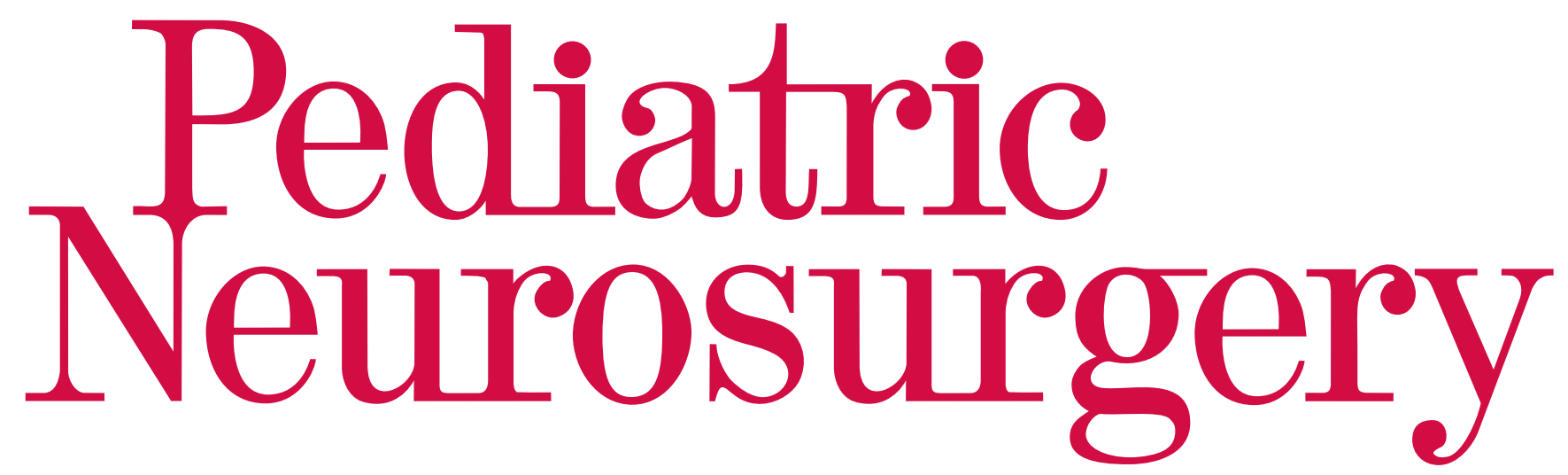

Original Papers

205 Delayed Intracranial Hypertension and Cerebral Edema in Severe Pediatric Head Injury: Risk Factor Analysis

Bennett Colomer, C. (Valparaíso/Viña del Mar); Solari Vergara, F.; Tapia Perez, F.;

Miranda Vasquez, F. (Viña del Mar); Horlacher Kunstmann, A.; Parra Fierro, G. (Valparaíso); Salazar Zenkovich, C. (Valparaíso/Viña del Mar)

210 Primary Tethered Cord Syndrome - Clinical and Urological Manifestations, Diagnosis and Management: A Prospective Study

Ailawadhi, P.; Kale, S.S.; Agrawal, D.; Mahapatra, A.K.; Kumar, R. (New Delhi)

216 Extradural Hematoma in Children: Case Series of 33 Patients

Hardtke Teichert, J.; Rosales Jr., P.R.; Blanco Lopes, P.; Valency Enéas, L.; Sica da Rocha, T. (Porto Alegre)

221 Is Repeat Head Computed Tomography Necessary in Children Admitted with Mild Head Injury and Normal Neurological Exam?

Dawson, E.C.; Montgomery, C.P.; Frim, D.; Koogler, T. (Chicago, Ill.)

225 Could Craniometric Measurements Explain the Growth of the Superior Sagittal Sinus?

de Souza, R.B.; Pinto, F.C.G. (Sao Paulo)

229 Terminal Myelocystocele: A Series of $\mathbf{3 0}$ Cases and Review of the Literature Tandon, V.; Garg, K.; Mahapatra, A.K. (New Delhi)

Case Reports

236 Symptomatic Spinal Cord Compression from an Intradural Arachnoid Cyst with Associated Syrinx in a Child: Case Report

Su, D.K.; Ebenezer, S.; Avellino, A.M. (Seattle, Wash.) 


\section{Pediatric
Neurosurgery}

(Continued from front cover)

240 Uterus-Like Mass in Association with Neural Tube Defect: A Case Report and Review of the Literature

Kakkar, A.; Sharma, M.C.; Garg, A.; Goyal, N.; Suri, V.; Sarkar, C.; Mahapatra, A.K. (New Delhi)

245 Anaplastic Ganglioglioma in the Spinal Cord: Case Report and Literature Review Kuten, J.; Kaidar-Person, O.; Vlodavsky, E.; Postovsky, S.; Billan, S.; Kuten, A.; Bortnyak-Abdah, R. (Haifa)

249 Anaesthetic Management of a Giant Encephalocele: Size Does Matter Singh, N.; Rao, P.B. (Pondicherry); Ambesh, S.P.; Gupta, D. (Lucknow)

253 Temporal and Optic Pathway Pilomyxoid Astrocytoma Mimicking Dural-Based Lesion: Case Report and Review of the Literature

Edwards, J.R.; Kulwin, C.G.; Martin, S.E.; Wilson, S.; Ho, C.Y.; Fulkerson, D.H. (Indianapolis, Ind.)

Images in Pediatric Neurosurgery

258 Chronic Headaches due to Periventricular Nodular Heterotopia Causing Obstructive Hydrocephalus

Singleton, W.G.B.; Bacon, A.; Edwards, R.J. (Bristol)

261 Cranium Bifidum Occultum

Vedajallam, S.; Chacko, A. (Pretoria); Andronikou, S. (Johannesburg); Truter, R.; White, G.

(Cape Town)

264 Vertebral Anomalies in Siblings with Fanconi Anemia

Houten, J.K.; Nasser, R. (Bronx N.Y.)

267 Announcements 


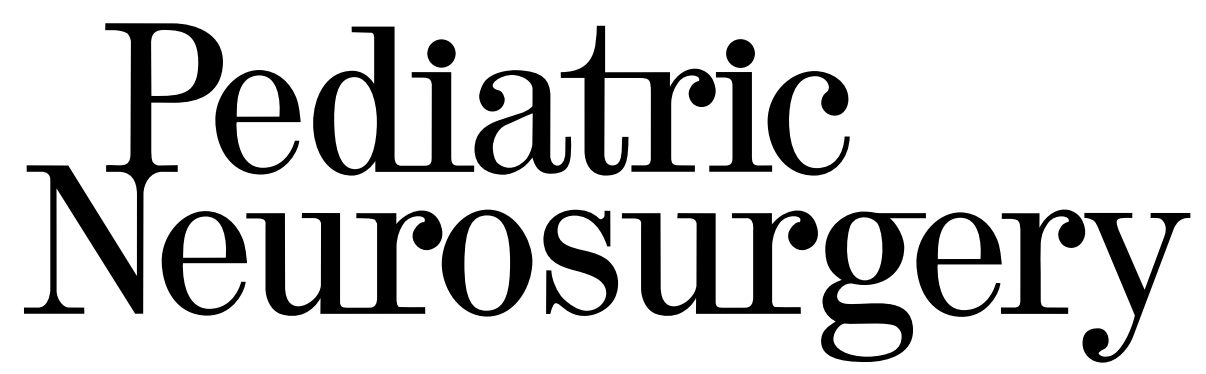

Founded 1985 by E.B. Hendrick and D.H. Reigel

Editor-in-Chief 1985-1991: E.B. Hendrick

Editor-in-Chief 1992-1996: F.J. Epstein

Managing Editor 1985-1998: D.H. Reigel

Editor-in-Chief 1997-2002: D.G. McLone

Managing Editor 1998-2003: M.L. Walker

Editor-in-Chief 2002-2003: W.J. Oakes

\section{Editor-in-Chief}

David M. Frim, Chicago, Ill.

\section{Senior Advisory Board}

\section{J. Gordon McComb,}

Los Angeles, Calif.

David G. McLone, Chicago, Ill.

Donald H. Reigel, Wexford, Pa.

Ken R. Winston, Denver, Colo.

\section{Editorial Board}

H. AbdelAziz, Amman

Y. Aihara, Tokyo

A.M. Avellino, Seattle, Wash.

D.M.E. Bardo, Portland, Oreg.

S. Constantini, Tel Aviv

H.I. El-Shafei, Cairo

T.M. George, Austin, Tex.

J.A. Grant, Kansas City, Kans.

D.K. Gupta, New Delhi

R. Hakim, Beachwood, Ohio

G.I. Jallo, Baltimore, Md.
M. Kohrman, Chicago, Ill.

M.D. Krieger, Los Angeles, Calif.

D.P. Muzumdar, Mumbai

J. Pattisapu, Orlando, Fla.

C. Roberts, Portland, Oreg.

M.U. Schuhmann, Tübingen

N.R. Selden, Portland, Oreg.

S. Sgouros, Athens

M. Stoodley, Sydney, N.S.W.

M. Vassilyadi, Ottawa
Appears bimonthly: 1 volume per year (6 issues) 


\section{Pediatric
Neurosurgery}

\section{Submission}

Only original papers written in English are considered and should be submitted using the online submission website at:

$$
\text { www.karger.com/pne }
$$

or as e-mail attachment (the preferred word-processing package is MS-Word) to the Editorial Office:

\section{pne@karger.com}

S. Karger AG

Editorial Office Pediatric Neurosurgery

$\mathrm{CH}-4009$ Basel (Switzerland)

Tel. +41613061357

\section{Conditions}

All manuscripts are subject to editorial review. Manuscripts are received with the explicit understanding that they are not under simultaneous consideration by any other publication. Submission of an article for publication implies transfer of the copyright from the author to the publisher upon acceptance. Accepted papers become the permanent property of 'Pediatric Neurosurgery' and may not be reproduced by any means, in whole or in part, without the written consent of the publisher. It is the author's responsibility to obtain permission to reproduce illustrations, tables, etc. from other publications.

Sections

The journal consists of the following sections:

- Reviews

- Original Papers

- Novel Insights from Clinical Practice

- Technical Notes

- Images in Pediatric Neurosurgery

- Letters to the Editor

Reviews are either invited by the editor or may be submitted for consideration.

Novel Insights from Clinical Practice (formerly Case Reports): Maximum 7 authors. The publication space available for case reports is very limited. The journal only considers case reports with significant new insights or with an extremely unusual and memorable course. Highlighted boxes containing one or two bullet points on ,Established facts' (what is already known) and ,Novel insights' (what new information has been gained) are required and should be placed on the first page of the report. These should be selected so as to reinforce the novelty of the clinical observation. The text per box should be limited to 1-2 very short sentences. The manuscript should be presented with an abstract (unstructured, max. 200 words), followed by introduction, case report and discussion. Maximum 3 figures.

Technical Note: This section contains articles which describe modern operative techniques in the field of pediatric neurosurgery. Manuscripts should be short and precise and should contain an abstract, 5 key words and 1-4 figures to explain the surgical procedure.

Images in Pediatric Neurosurgery: The section offers the possibility to share an exceptional clinical condition encountered during daily work. Images must be original, unpublished, high-quality black-and-white photographs. The legend/short text should explain the uniqueness of the depicted image and provide relevant clinical information including a short description of the patient's history, relevant physical and laboratory findings, clinical course, response to treatment (if any) and condition, or both. Maximum 8 references, 3 figures; no abstract necessary and no key words.

Letters to the Editor are encouraged if they directly concern articles previously published in this journal and clinical subjects related to the matters discussed. The editor reserves the right to submit copies of such letters to the authors of the articles concerned prior to publication in order to permit them to respond in the same issue of the journal. Letters to the Editor should be no longer than one printed page.

\section{Arrangement}

Title page: The first page of each paper should indicate the title, the authors' names, the institute where the work was conducted, and a short title for use as running head.

Full address: The exact postal address of the corresponding author complete with postal code must be given at the bottom of the title page. Please also supply phone and fax numbers, as well as e-mail address.

Key words: Please supply 3-10 key words in English that reflect the content of the paper.

Abstract: Each paper needs an abstract of up to 10 lines.

Footnotes: Avoid footnotes. When essential, they are numbered consecutively and typed at the foot of the appropriate page.

Tables and illustrations: Tables and illustrations (both numbered in Arabic numerals) should be prepared on separate sheets. Tables require a heading and figures a legend, also prepared on a separate sheet. For the reproduction of illustrations, only good drawings and origina photographs can be accepted; negatives or photocopies cannot be used. Due to technical reasons, figures with a screen background should not be submitted. When possible, group several illustrations on one block for reproduction (max. size $180 \times 223 \mathrm{~mm}$ ) or provide crop marks. Electronically submitted b/w half-tone and color illustrations must have a final resolution of $300 \mathrm{dpi}$ after scaling, line drawings one of 800-1200 dpi.

\section{Color illustrations}

Online edition: Color illustrations are reproduced free of charge. In the print version, the illustrations are reproduced in black and white. Please avoid referring to the colors in the text and figure legends.

Print edition: Up to 6 color illustrations per page can be integrated within the text at CHF 800.- per page.

References: In the text identify references by Arabic numerals [in square brackets]. Material submitted for publication but not yet accepted should be noted as 'unpublished data' and not be included in the reference list. The list of references should include only those publications which are cited in the text. Do not alphabetize; number references in the order in which they are first mentioned in the text. The surnames of the authors followed by initials should be given. There should be no punctuation other than a comma to separate the authors. Preferably, please cite all authors. Abbreviate journal names according to the Index Medicus system. Also see International Committee of Medical Journal Editors: Uniform requirements for manuscripts submitted to biomedical journals (www.icmje.org).

\section{Examples}

(a) Papers published in periodicals: Sun J, Koto H, Chung $\mathrm{KF}$ : Interaction of ozone and allergen challenges on bronchial responsiveness and inflammation in sensitised guinea pigs. Int Arch Allergy Immunol 1997;112:191195.

(b) Papers published only with DOI numbers:

Theoharides TC, Boucher W, Spear K: Serum interleukin-6 reflects disease severity and osteoporosis in mastocytosis patients. Int Arch Allergy Immunol DOI: $10.1159 / 000063858$

(c) Monographs: Matthews DE, Farewell VT: Using and Understanding Medical Statistics, ed 3, revised. Basel, Karger, 1996

(d) Edited books: Parren PWHI, Burton DR: Antibodies against HIV-1 from phage display libraries: Mapping of an immune response and progress towards antiviral im- munotherapy; in Capra JD (ed): Antibody Engineering. Chem Immunol. Basel, Karger, 1997, vol 65, pp 18-56.

Reference Management Software: Use of EndNote is recommended for easy management and formatting of citations and reference lists.

\section{Digital Object Identifier (DOI)}

S. Karger Publishers supports DOIs as unique identifiers for articles. A DOI number will be printed on the title page of each article. DOIs can be useful in the future for identifying and citing articles published online without volume or issue information. More information can be found at www.doi.org.

\section{Supplementary Material}

Supplementary material is restricted to additional data that are not necessary for the scientific integrity and conclusions of the paper. Please note that all supplementary files will undergo editorial review and should be submitted together with the original manuscript. The Editors reserve the right to limit the scope and length of the supplementary material. Supplementary material must meet production quality standards for Web publication without the need for any modification or editing. In general, supplementary files should not exceed $10 \mathrm{MB}$ in size. Al figures and tables should have titles and legends and all files should be supplied separately and named clearly. Acceptable files and formats are: Word or PDF files, Excel spreadsheets (only if the data cannot be converted properly to a PDF file), and video files (.mov, .avi, .mpeg).

\section{Author's Choice ${ }^{\mathrm{TM}}$}

With this option the author can choose to make his article freely available online against a one-time fee of CHF 3000.-. This fee is independent of any standard charges for supplementary pages, color images etc. which may apply. More information can be found at www.karger.com/authors choice.

\section{NIH-Funded Research}

The U.S. National Institutes of Health (NIH) mandates under the NIH Public Access Policy that final, peer-reviewed manuscripts appear in its digital database within 12 months of the official publication date. As a service to authors, Karger submits the final version of your article on your behalf to PubMed Central (PMC) immediately upon publishing. It usually receives a PMCID within approximately a month and will appear in PMC after 12 months. For those selecting our premium Author's Choi$\mathrm{ce}^{\mathrm{TM}}$ service, the usual embargo will be overriden, accelerating the accessibility of your work. More details on NIH's Public Access Policy are available at http://publicaccess.nih.gov/policy.htm

\section{Self-Archiving}

Karger permits authors to archive their pre-prints (i.e. pre-refereeing) or post-prints (i.e. final draft post-refereeing) on their personal or institution's servers, provided the following conditions are met: Articles may not be used for commercial purposes, must be linked to the publisher's version, and must acknowledge the publisher's copyright. Authors selecting Karger's Author's Choice ${ }^{\mathrm{TM}}$ feature, however, are also permitted to archive the final, published version of their article, which includes copyediting and design improvements as well as citation links.

\section{Proofs}

Unless indicated otherwise, proofs are sent to the corresponding author and should be returned with the least possible delay. Alterations made in proofs, other than the correction of printer's errors, are charged to the author.

\section{Reprints}

Order forms and a price list are sent with the proofs. Orders submitted after the issue is printed are subject to considerably higher prices.

\section{KARGER}

E-Mail karger@karger.com www.karger.com
(C) 2012 S. Karger AG, Basel 


\section{Pediatric \\ Neurosurgery}

ISSN Print Edition: 1016-2291

ISSN Online Edition: 1423-0305

Journal Homepage: www.karger.com/pne

Publication Data: 'Pediatric Neurosurgery' is published 6 times a year. Volume 48 with 6 issues appears in 2012 .

Copyright: (c) 2011 S. Karger AG, Basel (Switzerland) All rights reserved. No part of this publication may be translated into other languages, reproduced or utilized in any form or by any means, electronic or mechanical including photocopying, recording, microcopying, or by any information storage and retrieval system, without permission in writing from the publisher or, in the case of photocopying, direct payment of a specified fee to the Copyright Clearance Center.

Disclaimer: The statements, opinions and data contained in this publication are solely those of the individual authors and contributors and not of the publisher and the editor(s). The appearance of advertisements in the journal is not a warranty, endorsement, or approval of the products or services advertised or of their effectiveness, quality or safety. The publisher and the editor(s) disclaim responsibility for any injury to persons or property resulting from any ideas, methods, instructions or products referred to in the content or advertisements.
Subscription Rates: Subscriptions run for a full calendar year. Prices are given per year. Personal subscription

Print or Online

CHF 506.-

EUR 404--

USD 491.00

Print+Online combined

USD 538.00

postage and handling (added to print and print+online)

CHF 40.80 Europe, CHF 60.- Overseas

EUR 31.20

USD 56.40

Institutional subscription

Print or Online

Print+Online combined

CHF 1685.-

EUR 1348.-

CHF 1845.-

postage and handling (added to print and print+online)

CHF 51.00 Europe, CHF 75.00 Overseas

EUR 39.00

USD 70.50

Airmail surcharge: CHF 51.00 / USD 48.00
Back Volumes and Single Issues: Information on availability and prices of single print issues and print or electronic back volumes can be obtained from Customer Service at service@karger.ch.

Bibliographic Indices: This journal is regularly listed in bibliographic services, including Current Contents ${ }^{\circledR}$ and PubMed/MEDLINE.

Photocopying: This journal has been registered with the Copyright Clearance Center (CCC), as indicated by the code appearing on the first page of each article. For readers in the US, this code signals consent for copying of articles for personal or internal use, or for the personal or internal use of specific clients, provided that the stated fee is paid per copy directly to

Copyright Clearance Center Inc.

222 Rosewood Drive

Danvers, MA 01923 (USA)

A copy of the first page of the article must accompany payment. Consent does not extend to copying for general distribution, for promotion, for creating new works, or for resale. In these cases, specific written permission must be obtained from the copyright owner,

S. Karger AG, P.O. Box

CH-4009 Basel (Switzerland).

\section{Subscription Orders}

Orders can be placed at agencies, bookstores, directly with the Publisher

\section{S. Karger AG}

Medical and Scientific Publishers

Allschwilerstrasse 10

CH-4009 Basel

Switzerland

+416130611 11

f: +41613061234

e: karger@karger.com

w: www.karger.com

(for courier services only:

Allschwilerstrasse 10

CH-4055 Basel) or further Karger offices

or representatives:

Germany

S. Karger GmbH

Postfach

79095 Freiburg

Deutschland

(Hausadresse: Wilhelmstrasse 20A,

79098 Freiburg)

$\mathrm{t}: \quad+49761452070$

f: +497614520714

e: information@karger.de

w: www.karger.de

apan

Karger Japan, Inc.

Shiba Daimon Asahi Bldg. 2F

1-2-23 Shiba Daimon

Minato-ku

Tokyo 105-0012

Japan

$\mathrm{t}:+81364356242$

$\mathrm{f:}+81364356244$

e: publisher@karger.jp

w: www.karger.jp
USA

S. Karger Publishers, Inc.

26 West Avon Road

P.O. Box 529

Unionville, CT 06085

USA

Toll free: +18008285479

t: +18606757834

$\mathrm{f}: \quad+18606757302$

e: karger@snet.net

France

Librairie Médi-Sciences Sar

36, bd de Latour-Maubourg

75007 Paris

France

$\mathrm{t}:+33(0) 145514258$

f: $+33(0) 145560780$

e: librairie@medi-sciences.fr

w: www.medi-sciences.fr
South East Asia, China and Taiwan

Karger Regional Office (Malaysia)

CEO Suite Kuala Lumpur

Quill 7, 27th Floor

Jalan Stesen Sentral 5

KL Sentral

Kuala Lumpur 50470

Malaysia

$\mathrm{t}:+60327766803$

f: +60327766999

e: service@karger.cn; r.chew@karger.cn

\section{Karger China}

10th Floor, Twin Towers (East)

B12 Jianguomenwai Avenue

Beijing 100022

China

$\mathrm{t}:+861051235033$

f: +861051235122

e: service@karger.cn; r.chew@karger.cn

w: www.karger.cn

India, Bangladesh, Sri Lanka

Medscience India

Plot No. 17, Yusuf Sarai Market

B.L. Glass Building, 2nd Floor

Sri Aurobindo Marg

New Delhi 110016

India

t: +911146029633

f: +911146029634

c: +919891052128

e: medsci.india@gmail.com

Change of Address:

Both old and new address should be sent

to the subscription source.

\section{KARGER}

E-Mail karger@karger.com www.karger.com
(C) 2012 S. Karger AG, Basel

The Journal Home Page is available at: www.karger.com/pne 


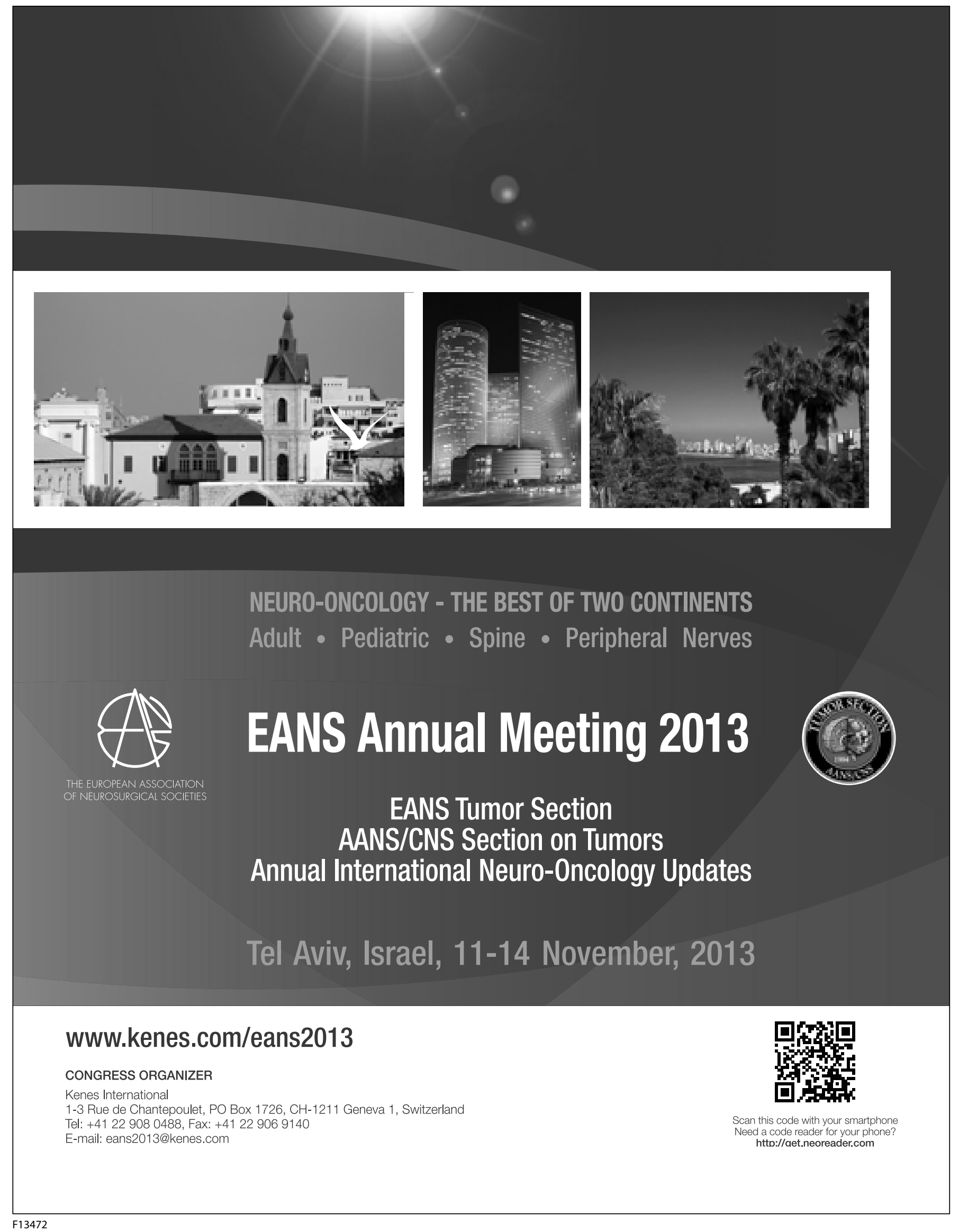




\section{Contents}

See the journal website for contents

KARGER Basel $\bullet$ Freiburg $\cdot$ Paris $\bullet$ London $\bullet$ New York $\cdot$ New Delhi $•$ Bangkok Beijing $\cdot$ Tokyo $\cdot$ Kuala Lumpur $\cdot$ Singapore $\bullet$ Sydney 


\section{5 th Congress}

International Society of Craniofacial Surgery Jackson Hole, Wyoming September 10-14, 2013

\section{CONGRESS HIGHLIGHTS}

- Combined Neurosurgery/Craniofacial Surgery Preconference Symposium Management of Craniosynostosis: Conflicts and Consensus

- First Ortiz-Monasterio Memorial Lecture

- Founders Lecture Series

- Ceremony to award Tessier Medal

- International Presentations in I2 topic categories

- Breakout sessions:

- Craniofacial Orthodontics

- Clinical \& Basic Science Research

- Genetics and Non surgical Care in Hemifacial Microsomia

2013 Meeting Management Office International Society of Craniofacial Surgery 45 Lyme Road, Suite 304 Hanover, NH 03755 USA Tel: I-603-643-2325

Fax: I-603-643-I444

Email: ISCFS20I3@conmx.net
Hotels

Four Seasons Resort Snake River Lodge \& Spa Hotel Terra Teton Mountain Lodge \& Spa Inn at Jackson Hole 


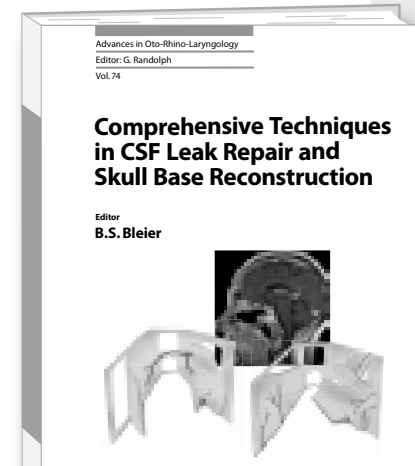

KARGER

\title{
Comprehensive Techniques in CSF Leak Repair and Skull Base Reconstruction
}

\author{
Editor \\ Benjamin S. Bleier
}

Comprehensive Techniques in CSF Leak Repair and Skull Base Reconstruction

Editor: Bleier, B.S. (Boston, Mass.)

$X+190$ p., 74 fig., 49 in color, 12 tab.,

online supplementary material, 2013

CHF 229.- / EUR 191.- / USD 269.00 (hard cover)

CHF 275.- / EUR 229.- / USD 323.00 (online)

Online version for institutional purchase

Prices subject to change

EUR price for Germany, USD price for USA only ISBN 978-3-8055-9952-8 (hard cover)

e-ISBN 978-3-8055-9953-5

Advances in Oto-Rhino-Laryngology, Vol. 74 Series Editor: Randolph, G. (Boston, Mass.) Listed in MEDLINE/Pubmed

\section{Os:

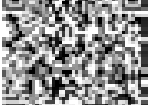

Dear Librarian

I have reviewed this publication and would like to recommend it for our library.

\section{Recommended by:}

Department:

Date:
Written by international leading experts in the field of skull base surgery, this publication provides a comprehensive description of both the etiology and management of defects arising in the anterior skull base. The contributions explore the cutting edge techniques in cranial base repair including free grafting, pedicled endonasal and extranasal grafts as well as free flap reconstruction. Further, this volume provides a detailed description of how to enhance success in cerebrospinal fluid leak and encephalocele repair using an evidence-based approach to the diagnosis and localization.

The contributions are accompanied by high-definition online videos that enable the reader to watch endoscopic skull base repairs performed by the masters while providing a step-by-step explanation of the techniques utilized.

Otolaryngologist, neurosurgeons as well as physicians interested in learning about or wishing to optimize their techniques in anterior skull base reconstruction will find this publication indispensable reading.

\section{Contents}

-Preface: Bleier, B.S.

-Skull Base Anatomy and CSF Rhinorrhea: Lam, A.; Holbrook, E.

-Pathophysiology of latrogenic and Traumatic Skull Base Injury: Gray, S.T.; Wu, A.W.

- Grafting Materials in Skull Base Reconstruction:

Prickett, K.K.; Wise, S.K.

- Free Graft Techniques in Skull Base Reconstruction: Ting, J.Y.; Metson, R.

- Nasoseptal Flap: Pinheiro-Neto, C.D.; Snyderman, C.H. -Sphenopalatine-Derived Pedicled Flaps: Suh, J.D.; Chiu, A.G.

-Anteriorly Based Pedicled Flaps for Skull Base

Reconstruction: Meier, J.C.; Bleier, B.S.

-Pedicled Extranasal Flaps in Skull Base

Reconstruction: Kim, G.G.; Hang, A.X.; Mitchell, C.A.;

\section{Zanation, A.M.}

- Microvascular Free Flaps in Skull Base

Reconstruction: Herr, M.W.; Lin, D.T.

-Spontaneous Cerebrospinal Fluid Leak and Management of Intracranial Pressure: Soler, Z.M.; Schlosser, R.J.

-Endoscopic Reconstruction of Frontal, Cribiform and Ethmoid Skull Base Defects: Chin, D.; Harvey, R.J. -Planum, Tubercular, Sellar and Clival Defects:

Wei, C.C.; Palmer, J.N.

-Quality Control Approach to Cerebrospinal Fluid

Leaks: Snyderman, C.H.; Gardner, P.A.

- Postoperative Care following Skull Base

Reconstruction: Ramakrishnan, V.R.; Waziri, A.

-Complications of Skull Base Reconstruction:

Chaaban, M.R.; Woodworth, B.A.

-Prevention and Management of Complications after Radiotherapy for Skull Base Tumors: A Multidisciplinary Approach: Jang, J.W.; Chan, A.w. - Novel Techniques and the Future of Skull Base Reconstruction: Meier, J.C.; Bleier, B.S. 


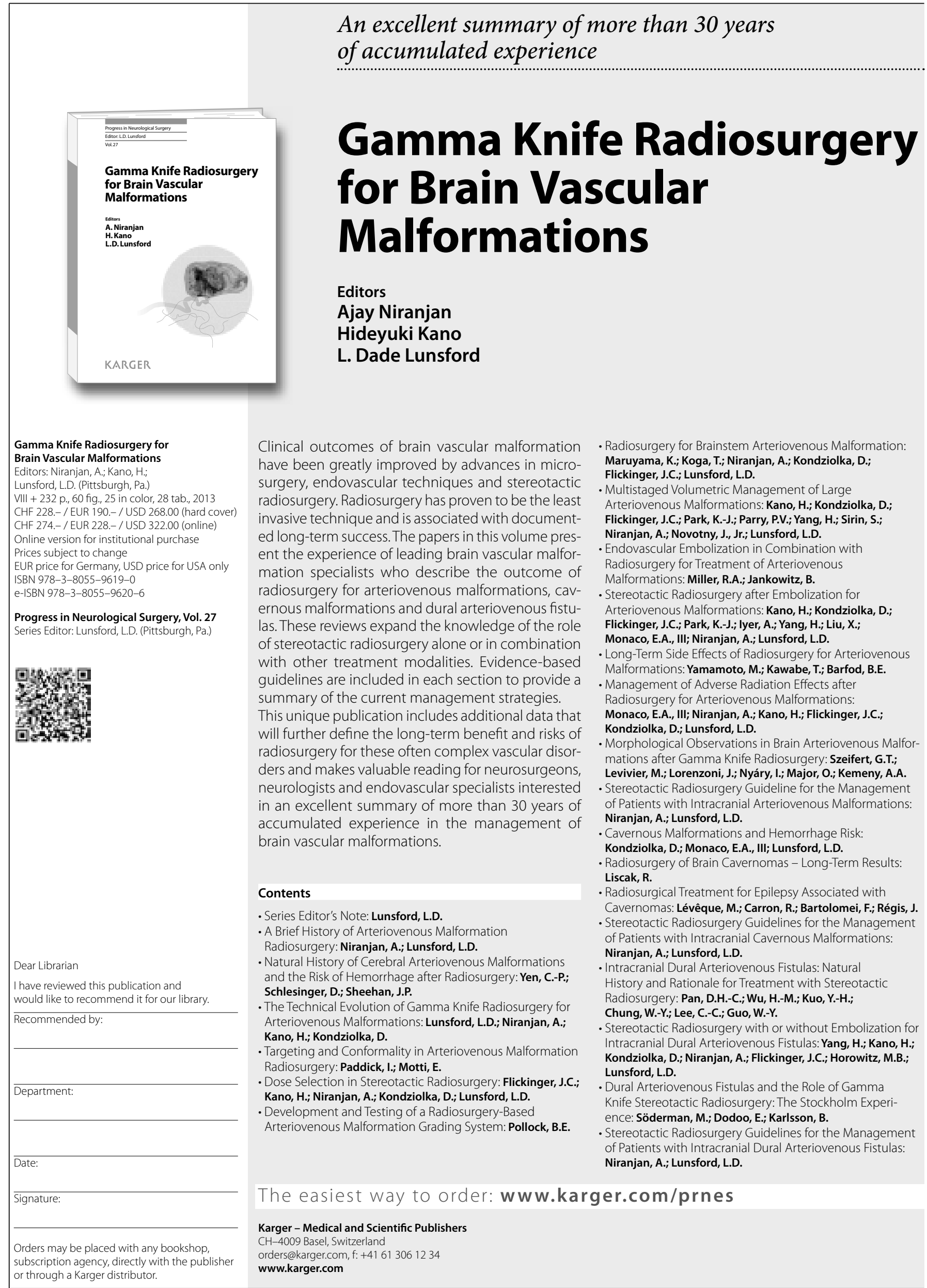


A new vision to understanding medicine Handbook of Clinical Gender Medicine

Editors: Karin Schenck-Gustafsson (Stockholm), Paula R. DeCola, Donald W. Pfaff (New York, N.Y.), David S.Pisetsky (Durham N.C.)

In well-referenced chapters, experts cogently and concisely explain how the incorporation of gender issues into research can affect the medical understanding and treatment of heart disease, osteoporosis, arthritis, pain as well as malaria among other conditions.

This intriguing and unique medical textbook provides readers with a valuable new perspective on how to incorporate gender issues into the different branches of medicine.

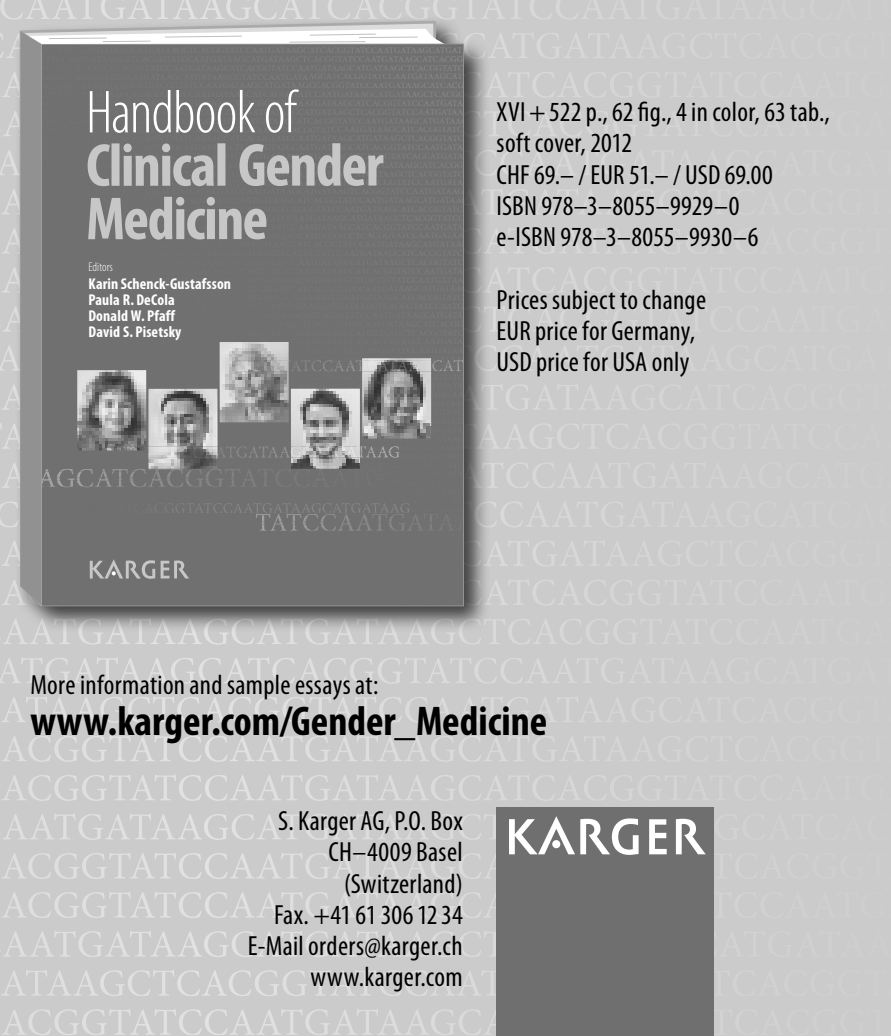

\section{KARGER BOOKS ON MEDICAL PHILOSOPHY}

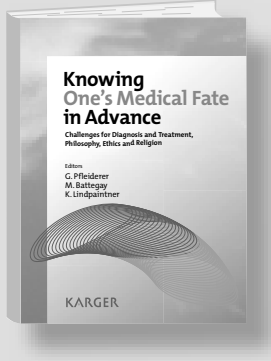

\section{Knowing One's}

\section{Medical Fate in Advance}

Challenges for Diagnosis and Treatment, Philosophy, Ethics and Religion

Editors: G. Pfleiderer, M. Battegay, K. Lindpainter

$\mathrm{VI}+122$ p., 4 fig., 2 in color, hard cover, 2012

CHF 59. - / EUR 49.- / USD 69.00

ISBN 978-3-8055-9649-7
The certainty and uncertainty of one's fate are discussed from both methodological and epidemiological perspectives, using examples of diseases for which treatment and prognosis have dramatically changed. Despite profound insights into the human genome, personalized genetically tailored medicine still lies in the future. Religious, spiritual and philosophical dimensions are discussed, as are the ways in which they may help people cope with these new insights into their future, e.g. the promise of an afterlife.

This publication aims to bridge the different fields dealing with this area by addressing the challenges faced and encouraging dialogue. It will be of interest to all readers who deal with ethical problems of prognosis, particularly in medicine, as well as to theologians and sociologists.

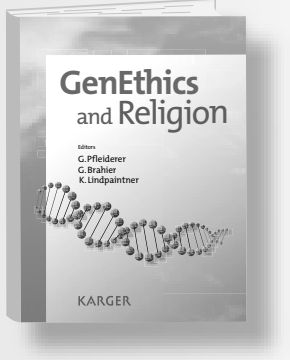

\author{
GenEthics and Religion \\ Editors: G. Pfleiderer, G. Brahier \\ K. Lindpaintner \\ $\mathrm{VI}+154 \mathrm{p}$., hard cover, 2010 \\ CHF 29. - / EUR 24. - / USD 34.00 \\ ISBN 978-3-8055-8973-4 \\ Prices subject to change; \\ EUR price for Germany, USD price for USA only
}

Based on the symposium 'GenEthics and Religion' (Basel, Switzerland, May 2008), this volume examines the role religion can play in establishing ethical guidelines to protect human life in the face of rapid advances in biology and gene technology. It does so with contributions by philosophers, theologians, human geneticists, and several bioethicists representing the Christian, Jewish, Islamic and Buddhist perspectives. The essays illustrating a diversity of views and expressing the problems and self-critical reflectiveness of religious ethicists are brought up to date and discuss the importance of religious ethics in society's discourse on gene technology. www.karger.com/philosophy 


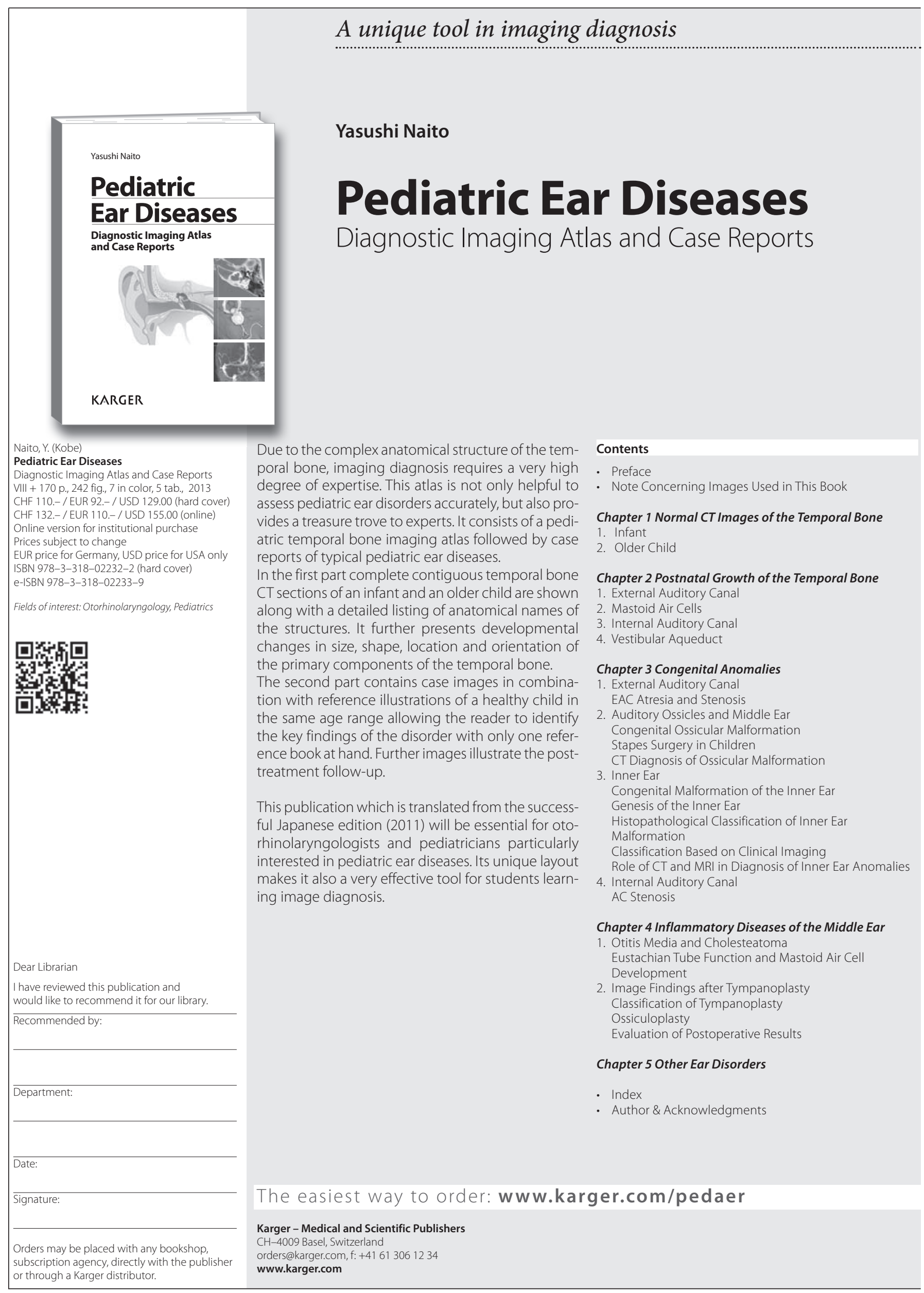




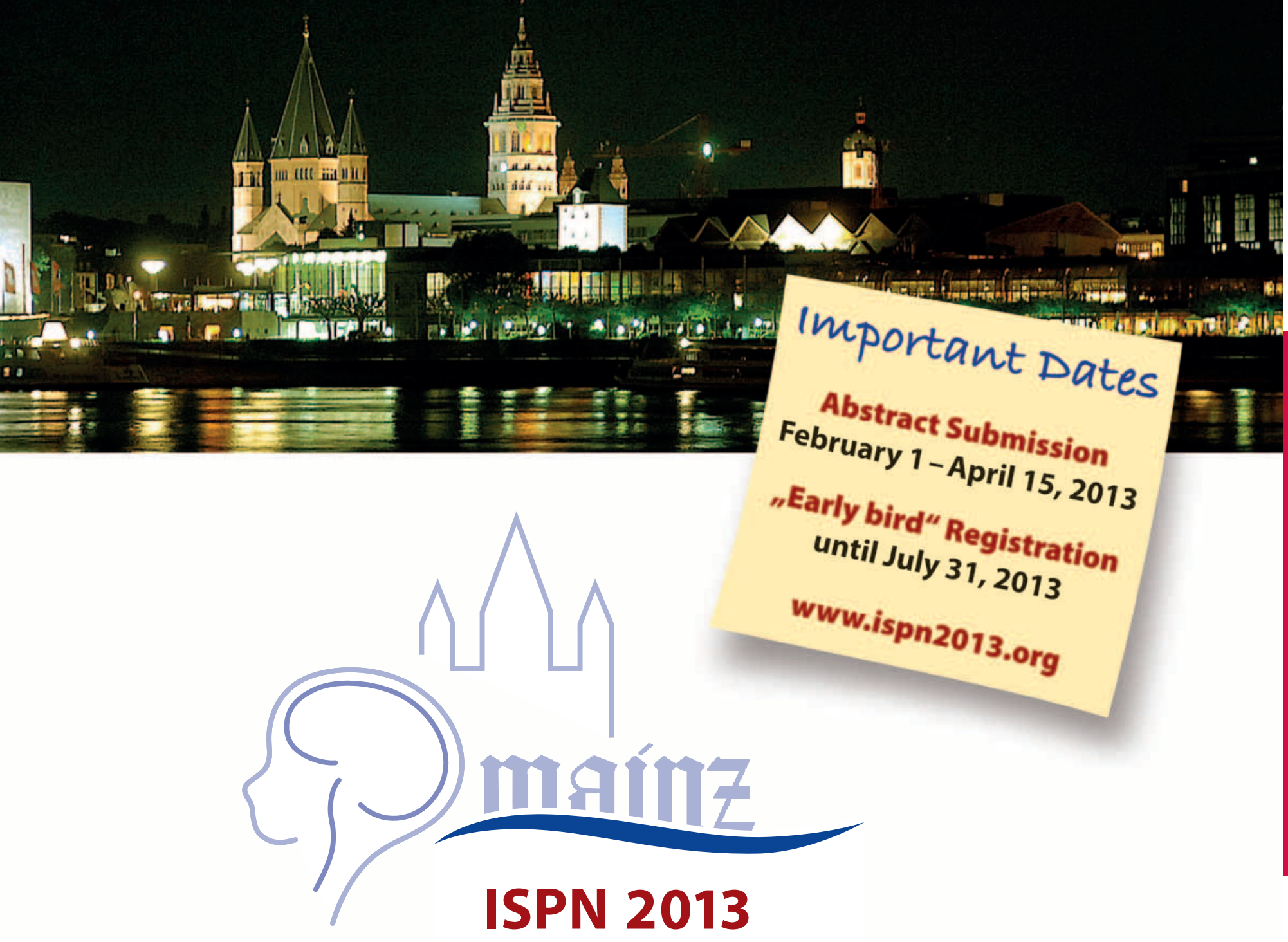

International Society for

Pediatric Neurosurgery

41. Annual Meeting

Mainz - Germany

Sept 29 - Oct 3, 2013

www.ispn2013.org 